Valentin Molodychenko

ORCID: 0000-0002-9508-1383

Natalia Molodychenko

ORCID: 0000-0001-7699-0694

Yekaterina Kuchina

ORCID: 0000-0002-1701-8763

Andriej Orlov

ORCID: 0000-0003-0243-7313

Melitopolski Państwowy Uniwersytet Pedagogiczny

im. Bogdana Chmielnickiego, Melitopol, Ukraina

\title{
Повышение гражданской активности людей с инвалидностью
}

\section{Increasing civic activity of people with disabilities}

https://doi.org/10.34739/sn.2019.19.18

\begin{abstract}
Аннотация: В Украине формируется нормативно-правовое поле включение людей с инвалидностью в процессе развития демократического государства через усиление их гражданской активности. Методика исследования включала методы кабинетного исследования, фокус-группы, глубинное интервью, анкетирования и включала людей с инвалидностью возрастом 18-55 лет а также их родственников, друзей, представителей власти, жителей города позволила констатировать недостаточный уровень гражданской активности людей с инвалидностью. Качественной мотивацией для включения людей с инвалидностью в активную общественность деятельность могут быть совместные инициативы власти и общественных организаций, одной из форм которых могут быть проекты социальной направленности для развития демократического общества. Опыт деятельности Благотворительной организации «Социальный фонд» описан в этой статье. Ключевые слова: гражданская активность, инклюзия, инклюзивная образовательная среда, неформальное образование взрослых, образовательные потребности, обучающаяся молодежь
\end{abstract}

Abstract: In Ukraine the regulatory and legal field is being formed with the main purpose to include people with disabilities, through strengthening their citizen advocacy, in the process of developing a democratic state. In this article the experience of the Social Fund, a charitable organization, is described. The research methodology included desk research methods, focus groups, clinical interviews, questionnaires including people with disabilities aged 18-55 and also their relatives, friends, government officials, and city residents, which allowed the 
determination of the insufficient level of citizen advocacy of people with disabilities. Qualitative motivation for the inclusion of people with disabilities in the active public activity may be joint initiatives of the authorities and public organizations, one of the forms of which may be social projects for the development of democratic society.

Keywords: citizen advocacy, inclusion, inclusive educational environment, non-formal adult education, educational needs, learner

\section{Актуальность}

Гражданское общество, как социокультурный и общественнополитический феномен, объединяет социальные институты, социальные практики, общественные ценности [Степаненко, 2001, с. 4]. Активное участие всех граждан в общественной жизни является залогом успеха и прогресса общества. Гражданская, политическая, культурная, социальная активность зависит от подготовки к такой деятельности. Сегодня Украина испытывает потребность в подготовке и воспитании нового поколения граждан на основе ценностей демократического общества- верховенства прав человека, равенства и взаимной ответственности. Вопросы построения демократического общества, поиск способов взаимодействия человека с обществом, соблюдение прав и обязанностей граждан, возможностей активного участия в жизни общества находятся в центре внимания современных ученых.

Понятие «гражданская активность» исследуется в работах Т. Безверхой, Н. Деревянко, И. Жадан, В. Поплужного, К. Черной, С. Рябова и др. Особенности формирования гражданской активности молодежи рассматривали А. Нисимчук, Н. Побирченко, И. Прокопенко, А. Собчук, Л. Чеботарев, П. Шемякин, Н. Юрчук и др.

Социальный аспект активности рассматривается в работах М. Боришевского, В. Вороны, С. Войтовича, Е. Головахи, Н. Паниной и др.; влияние социальной политики на институты гражданского общества исследуют Г. Голеусова, В. Жукова, М. Лукашевич, Ю. Саенко, В. Скуратовский, В. Судаков, М. Туленков и др.; психолого-педагогические механизмы, условия, пути ее формирования - А.Бойко, И.Бех, М. Боришевский, Н. Ганусевич, О. Сухомлинская, В. Оржеховская, В. Плахтийи др.

Расширению сферы образования Украины способствует, прежде всего, развитие неформального образования для всех граждан. Ученые 
исследуют проблемы непрерывного образования и образования взрослых (В. Луговой, Л. Лукьянова, Н. Ничкало и др.). Несмотря на большое количество исследований, имеет место недостаточность научного обоснования именно образования взрослых людей с инвалидностью, рассмотрения повышения их гражданской активности.

Актуальной задачей остается поиск путей формирования гражданской активности всех граждан, особенно, молодежи. Образование для демократического гражданства фокусирует внимание на демократических правах и обязанностях, а также на активном участии в гражданской, политической, социальной, экономической, правовой и культурной сферах жизни общества [Хартия Совета Европы по Образованию, 2010]. Традиционные модели образования пока не соответствуют принципам обучения ответственных граждан, в которых нуждаются современные демократические общества. Необходимо внедрение новых форм обучения, направленных на подготовку молодежи к жизни в общества [Навчаємо демократії, 2016, с. 160].

Понятие «активность» - действие, поступок, то, что развивается. Ученые предлагают различное толкование активности: в социологии социальная активность, в политике - политическая активность, в педагогике и психологии - активность личности. Социальная активность - динамическое состояние личности, направленное на становление и поддержку ее связей с окружающим миром; совокупность форм человеческой деятельности, осознанно ориентированных на решение определенных задач, стоящих перед обществом, классом, социальной группой в определенный исторический период [Алексеенко, 2009, с. 412]. Активность - это своеобразное включенное обучение социальным навыкам, ответственности за свои действия.

Для современной молодежи актуальны различные формы социальной активности: гражданская, творческая и коммуникативная (интернет-активность), что может быть ресурсом для дальнейшего развития их гражданской активности в реальном пространстве. В социальной активности выделяют политическую, гражданскую, культурную, творческую, трудовую, коммуникативную, деловую активность.

Т. Безверхая считает, что гражданская активность - это внутреннее стремление к деятельности для осуществления определенной общественной цели [Безверхая, 2008, с. 18]. Большинство ученых 
считают, что гражданская активность - это структурно-содержательное качество личности, которое формируется и развивается на основе собственных ценностных ориентаций, учитывая ценности общества и правовые нормы и требования государства, направляет деятельность, поведение, общение человека на создание мира гражданских отношений и отражает характер институционального взаимодействия с властью. Основу гражданской активности составляют: интерес к общественной деятельности; организаторские способности; инициативность; требовательность к себе; ответственность за выполнение общественных поручений; готовность помогать другим. Сферами проявления гражданской активности является социальнокоммуникативная, общественная, общественно-политическая. Проявление гражданской активности способствует самореализации личности в той или иной социальной сфере. Формирование гражданской активности содержит следующие компоненты: формирование гражданской компетентности и ответственности в приобретении положительного опыта участия в общественной жизни; отношение гражданина к институтам власти и политической системы; изучение и усвоение демократических установок и ценностей; отношение гражданина к самому себе и к другим людям; усвоение политического словаря (когнитивный компонент политической культуры) [Бабкина, 2017, с. 130].

Необходимость гражданской активности всех граждан подчеркивается в документах: Глобальные цели ООН, Декларация ООН по образованию и воспитанию в области прав человека, Хартия Совета Европы по образованию для демократического гражданства и образования по правам человека, Закон Украины «Об образовании», Концепции развития инклюзивного образования и др., что предполагает консенсус национального и общеевропейского содержания гражданского образования. В Концепции развития гражданского образования в Украине конкретизируются основные гражданские компетентности: умение отстаивать свои права и права других; понимание и восприятие принципов равенства и не дискриминации; знание и понимание государственного устройства, принципов и путей формирования государственной политики во всех сферах общественной жизни; знание механизмов участия в общественной, общественнополитической и государственной жизни и умение их применять вместе 
с принятием решений; способность формировать и отстаивать собственную позицию, уважая мнения других, если они не нарушают прав и достоинств.

Интеграция Украины в европейские структуры требует новых подходов к решению проблем людей соціально уязвимых категорий, в частности, людей с инвалидностью, содействия развитию их гражданской активности. Опыт зарубежных стран свидетельствует, что главным направлением поддержки таких людей является реализация их прав, создание доступной и благоприятной среды для существования, возможностей обучения, трудоустройства, общения, отдыха, что является сферой заботы государства и общества.

Совет Европы гарантирует людям с инвалидностью: равный доступ ко всем видам образования, равные возможности учиться и работать вместе со здоровыми людьми, обучение на протяжении жизни, что способствует построению инклюзивного общества. В 2008 г. на 48 Международной конференции ЮНЕСКО отмечалось, что инклюзивное обучение играет важную роль в достижении гуманитарного, социального и экономического развития. Основной задачей инклюзии в образовании является ликвидация социальной изолированности (исключения). В Программе действий в отношении лиц с особыми потребностями, принятой на Саламанкской конференции, рекомендуется привлечение специалистов с особыми потребностями к обучению, разработка программы льготного обеспечения доступа к образованию взрослых с особыми потребностями: «должны быть разработаны специальные курсы, соответствующие потребностям и требованиям различных групп взрослых людей с недостатками» [Саламанкская декларация, 1994].

В Украине до настоящего времени не обеспечиваются необходимые стандарты уровня жизни людей с инвалидностью по причине их изоляции, отсутствия условий эффективной реализации их способностей, барьерности среды, что не способствует их интеграции в социум. Особенно это касается взрослых людей с инвалидностью, т.к. они обучались ранее в условиях советской системы образования у них зачастую сформированы стереотипы прошлого, которые не способствуют новому видению современных проблем и вариантов решения.

Для украинской системы образования инклюзия является педагогической инновацией, а с момента ратификации «Конвенции ООН 
о правах инвалидов» - одним из международных обязательств государства. В систему формального образования Украины вводятся принципы инклюзии, но вовлеченность взрослых людей с инвалидностью в программы неформального образования отсутствует. К тому же декларируется доступ всех взрослых людей к обучению на протяжении жизни [Лукьянова, 2011, с. 5].

В законодательстве Украины имеется противоречие между декларируемым правом на равный доступ ко всем звеньям образования для всех людей и недостаточной возможностью его реализовать из-за отсутствия условий для инклюзивной формы предоставления образования. Кроме того, отсутствуют механизмы внедрения инклюзии, а меры, предусмотренные в отдельных документах, служат лишь добрыми намерениями и не опираются на законодательную основу. В 2017 г. Верховная Рада приняла Закон «О внесении изменений в Закон Украины «Об образовании» - об особенностях доступа лиц с особыми образовательными потребностями к образовательным услугам». Этим Законом определяются понятия «лицо с особыми образовательными потребностями», «инклюзивное обучение» и др. Закон Украины «Об образовании», 2017 г. дает определение: инклюзивное обучение система образовательных услуг, гарантированных государством, основанная на принципах недискриминации, учета многообразия человека, эффективного привлечения и включения в образовательный процесс всех его участников.

В Государственной целевой программе «Национальный план действий по реализации Конвенции о правах инвалидов» на период до 2020 года предусмотрено обеспечение равного доступа к образованию; совершенствование условий оплаты труда специалистов, которые предоставляют образовательные услуги; увеличение численности лиц с инвалидностью, обучающихся в учебных заведениях ежегодно на 5 тыс., привлечение государственных органов, общественных, благотворительных организаций, которые занимаются проблемами людей с инвалидностью, к созданию благоприятных педагогических, психологических, медицинских, социально-экономических, организационно-правовых условий и гарантий для реализации их прав [Національний план дій, 2011].

Мы используем дефиниции, принятые в Украине: инклюзия (от Inclusion- включение) - процесс увеличения степени участия всех 
граждан в социальную жизнь, и прежде всего, тех кто имеет трудности в физическом и психическом развитии; цель инклюзии - создание такой социокультурной среды..., которая бы удовлетворяла индивидуальные образовательные потребности всех учащихся, независимо от особенностей их психофизического развития.

Инклюзивный подход к организации образования заключается в создании таких условий, при которых все имеют одинаковый доступ к образованию; одновременно все имеют возможность получить опыт, знания, которые способствуют преодолению предубеждений и дискриминации [Шевцив, 2016, с. 12]. Речь идет об инклюзивном обучении не только в формальном образовании и не только для школьников, а также - о формальном и неформальном образовании взрослых людей с инвалидностью, т.к. это один из путей их социализации, включения в социум, развития гражданской активности.

Гражданская активность людей с инвалидностью предполагает диалог «власти и городской общины» с инициативой от граждан, самих людей с инвалидностью. Одним из факторов, влияющим на формирование и развитие гражданской активности, является функционирование общественных организаций. На решение этой и подобных проблем направлены усилия Благотворительной организации «Социальный фонд» (г. Мелитополь, Украина). Цель организации осуществление благотворительной деятельности, содействие демократическому развитию общества в сферах образования, культуры, медицины, спорта, социальной защиты, благоустройства и туризма. Организация является членом Всеукраинского объединения ОО «Конфедерация общественных организация лиц с инвалидностью Украины», "Украинской ассоциации образования взрослых», Общественного совета и Комитета доступности при исполнительном комитете Мелитопольского городского совета. Благотворительная организация с 2015 года до настоящего времени реализовала 17 социальных проектов, из них 7 - при поддержке Немецкой ассоциации народных университетов DVV International в Украине и Федерального министерства экономического сотрудничества и развития Германии, например: в 2015 г. - «Повышение уровня гражданских компетенций представителей общественных организаций для содействия диалогу с властью»; «Мелитопольские голоса за демократию», как часть межрегионального проекта «Региональные 
голоса за демократию» и др. В 2016 г. были реализованы проекты: «Консолидация усилий провайдеров образовательных услуг в сфере формального и неформального образования взрослых для формирования гражданской компетентности жителей Запорожской области»; Международные дни образования взрослых в Запорожской области; «Сотрудничество библиотек и музеев Мелитопольщины, как ресурс развития образования взрослых», как часть всеукраинского проекта «Заменим стены открытыми окнами» и др.

Цель проекта «Включение людей с инвалидностью Мелитопольщины в демократические процессы общества», как части проекта «Региональные Голоса - Создаем Мосты для Демократии» повышение уровня участия людей с инвалидностью в демократических процессах общества путем развития их гражданской активности. Участниками проекта стали люди с инвалидностью, обучающиеся в условиях инклюзивных групп. Взаимодействие в проектах способствовало углублению знаний о политической культуре, инструментах демократии, бюджетном процессе в местном самоуправлении, медиаграмотности, взаимодействии со средствами массовой информации, лидерстве в общественном секторе, привлекало к адвокационным кампаниям для совершенствования местной политики в сфере построения инклюзивного пространства. Продолжением работы в указанной тематике стал проект «Летний лагерь для людей с инвалидностью «Познай свой край», реализованный при поддержке горродской власти и направленный на организацию отдыха и неформального обучения в сфере гражданского образования в инклюзивной группе.

Микропроект «Инклюзивная мастерская демократического диалога», как часть проекта «Региональные голоса - гражданское образование взрослых для расширения прав и возможностей локальных сообществ в Украине и Беларуси», реализуется при поддержке DVV International в Украине и Федерального министерства экономического сотрудничества и развития Германии. Основная гипотеза микропроекта повышение гражданской компетентности людей с инвалидностью будет способствовать осознанию своей роли в обществе, развитию гражданской активности и активному участию в общественнополитических процессах. С помощью полученных знаний и навыков, путем проведения адвокационных кампаний, люди с инвалидностью 
смогут способствовать формированию инклюзивного местного сообщества, что в перспективе создаст одинаково приемлемые условия проживания, образования, работы и досуга для всех категорий граждан.

На первом этапе команда Благотворительной организации «Социальный фонд» при участии эксперта А.Орлова провела комплексное исследование потребностей людей с инвалидностью в сфере гражданского образования для содействия развитию их гражданской активности путем повышения уровня гражданской компетентности.

Основная целевая группа- люди с инвалидностью, проживающие в разных районах города, в возрасте от 18 до 55 лет, независимо от гендерного статуса, группы инвалидности, семейного положения, социального статуса, образования, опыта гражданской активности, трудоустройства и стажа, мотивации к обучению; вспомогательная родственники и друзья людей с инвалидностью, представители власти, жители местного сообщества. География исследования г. Мелитополь Запорожской области (153 тыс. населения).

Кабинетное исследование на основе сбора вторичных данных позволило определить уровень гражданской активности людей с инвалидностью на основе документальных данных. Было выявлено, что:

- в городе реализуются несколько ежегодных Программ поддержки людей с инвалидностью, но они направлены, в основном, на оказание медицинской и реабилитационной помощи, мероприятий, преимущественно развлекательного и спортивного контента;

- в составе профильных общественных организаций лишь незначительное количество молодых людей с инвалидностью, в основном представлены люди третьего возраста. Низкая включенность людей с инвалидностью в общественные организации имеет место из-за неосведомленности об их существовании, а также из-за барьеров: внешних (архитектурная, транспортная недоступность, отсутствие поддержки близких); внутренних (изоляция, отсутствие навыков общения, состояние здоровья и др.). Вероятно, молодежь не входит в состав профильных общественных организаций и по другим причинам: не желают демонстрировать свою принадлежность $\mathrm{k}$ людям с инвалидностью, считают неинтересными мероприятия в организациях, предпочитают удовлетворить свою потребность в общении с помощью социальных сетей. Несмотря на то, что люди с инвалидностью имеют 
льготы при поступлении в учебные заведения, результаты анализа данных демонстрируют очень низкую их представленность среди студенческой молодежи: от 0 до 4\% от общего количества. Это связанно в большей мере с барьерами, которые непосильны для людей 1 группы инвалидности: внешними (архитектурная, транспортная недоступность, необеспеченность техническими средствами, методическая неготовность преподавателей, отсутствие поддержки близких, предвзятое отношение окружающих, материальные трудности); внутренними (низкая эффективность школьного обучения на дому, отсутствие навыков общения, неуверенность в собственных силах; в местных средствах массовой информации о людях с инвалидностью освещается, в основном, тематика об особенностях социальных выплат, реформ, участии в городских спортивных мероприятиях, реалиях оказания помощи, случаях инициирования строительства пандуса, проверок льготных перевозок в общественном транспорте (публикации СМИ за 3 года (2015-2018 гг.). Вместе с тем, индивидуальных примеров гражданской активности людей с инвалидностью в СМИ недостаточно.

Качественное исследование путем проведения фокус-групп (3 группы по 12 людей с инвалидностью с распределением по возрасту: 18-35 лет, 36-45 лет, 46-55 лет) позволило выявить их потребности в знаниях, умениях и навыках в сфере гражданского образования, исследовать и определить причины гражданской пассивности и мотивации к гражданской активности, необходимые знания и умения для формирования мотивации к обучению гражданской активности, уровень знаний об инструментах демократии участия, уровень понимания гражданского образования, ожидания от Программ гражданского образования. Во время проведения фокус-групп и глубинных интервью с людьми с инвалидностью ощущались трудности в низком уровне понимания гражданской активности.

Проведение качественного исследования путем глубинных интервью с 10 людьми с инвалидностью позволило конкретизировать потребности в сфере гражданского образования и выявить эффективные методы, формы, средства формирования гражданских компетентностей. Были определены оптимально эффективные методы и формы обучения, цели и задачи развития гражданской активности, ожидания от обучающих Программ, условия, которые нужно учитывать при обучении людей с инвалидностью и др. 
Результаты качественного исследования путем экспертного опроса методом фокусированного интервью с пятью представителями власти, которые работают с людьми с инвалидностью, стали основой для выявления наличия действующих городских Программ, в том числе образовательных, оценки уровня и необходимости повышения гражданской активности, выявления возможных путей улучшения предоставляемых услуг.

Проведение качественного исследования путем глубинных интервью $с$ пятью представителями близкого окружения людей с инвалидностью способствовало конкретизации и выявлению потребностей людей с инвалидностью в сфере гражданского образования, поиску эффективных методов, форм, средств и технологий формирования гражданских компетентностей, изучению роли и влияния близкого окружения на удовлетворение потребностей людей с инвалидностью, определению барьеров и факторов к обучению и гражданской активности, оценке уровня и необходимости повышения гражданской активности, с точки зрения близкого окружения. Проведение количественного исследования путем анкетирования людей с инвалидностью (n=100) позволило подтвердить потребности в сфере гражданского образования, выявленные во время качественного исследования, общий уровень знаний, умений в сфере гражданского образования, уровень готовности к образованию, уровень гражданской активности, сферы гражданской активности и ее проявления, факторы, влияющие гражданскую активность, методы развития компетентностей в сфере гражданского образования, ожидания от содержания Программ ит.д.

Среди причин неучастия в образовательных Программах основное место занимает состояние здоровья, на что указали $41,5 \%$ опрошенных (Рис. 1). Важной причиной так же является и отсутствие информации о подобных Программах (18,9\%). Так же люди с инвалидностью высказались о нехватке времени на обучение $(16,9 \%)$, отсутствии доступности Программ (15,1\%), большой цены за обучение («тренинги слишком дорого стоят») (1,9\%). Лишь 5,7\% опрошенных указали на то, что им не интересны подобные Программы.

Для половины опрошенных людей с инвалидностью основной целью гражданского образования является расширение круга общения, знакомых, друзей. Личностный рост и реализация интересна $26,7 \%$ 
опрошенных. Ожидают от обучения получить возможность быть кому-то полезным и помогать 25,7\%. Никто из респондентов не ставит целью получить славу и признание (0\%) (Рис. 2).

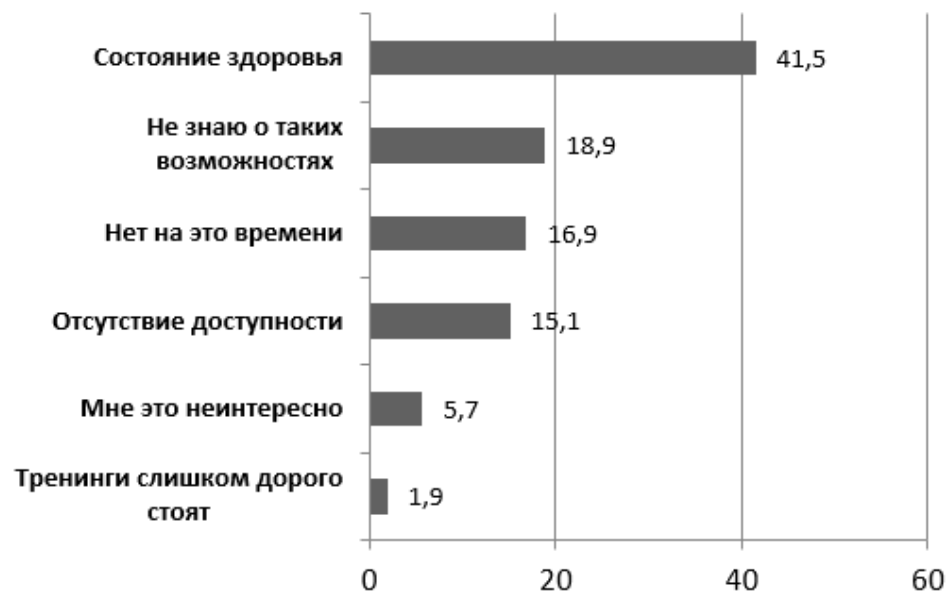

Рис. 1. Причины неучастия людей с инвалидностью в образовательных Программах* (результаты анкетного опроса среди людей с инвалидностью $(n=100) ; *$ респонденты имели возможность выбрать несколько вариантов ответа

Расширение круга общения, знакомых, друзей Личностный рост и реализация

Получить возможность быть кому-то полезным и помогать Желание побороть свои внутренние страхи и переживания Финансовая помощь Получение навыков публичных выступлений, отстаивания... Карьерный рост и профессиональный опыт Получить славу и признание

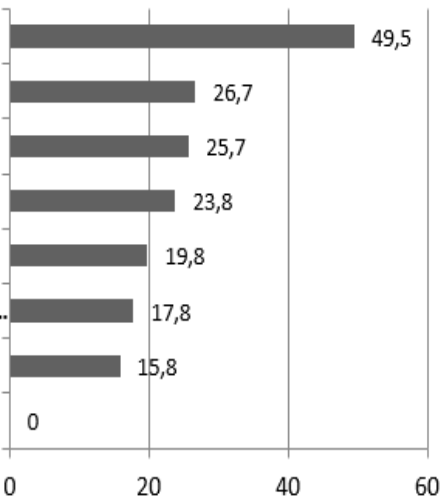

Рис. 2. Цели участия людей с инвалидностью в образовательных Программах* (результаты анкетного опроса среди людей с инвалидностью ( $\mathrm{n}=100)$

* респонденты имели возможность выбрать несколько вариантов ответа 
Важными потребностями людей с инвалидностью являются архитектурная доступность, материальное положение, доступность лекарств, возможность саморазвития и самореализации. Особенно удовлетворение обозначенных потребностей важно для категорий людей с инвалидностью с нарушениями зрения и слуха, а также для I группы инвалидности, передвигающихся на инвалидных колясках или тех, кто не имеет возможности передвижения.

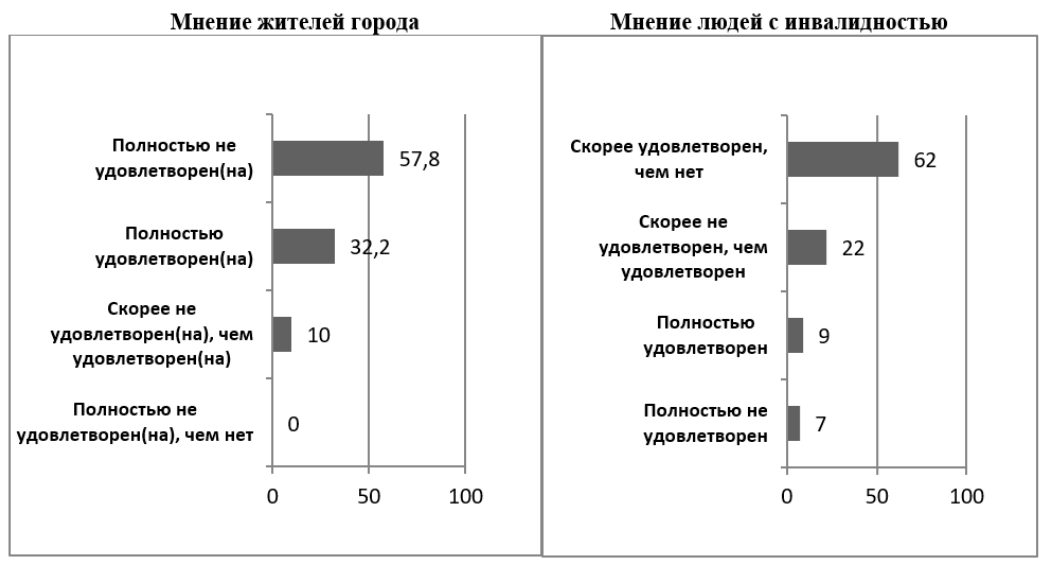

Рис. 3. Уровень удовлетворенности жизнью в городе (результаты анкетного опроса среди жителей города $(\mathrm{n}=100)$ и среди людей с инвалидностью $(\mathrm{n}=100)$

На этом во время полуструктурированного интервью акцентировали внимание представители власти, которые по роду деятельности общаются с указанной категорией. Было выявлено, что большинство горожан $(63,7 \%)$ и практически половина людей с инвалидностью $(44,1 \%)$ не имеют опыта участия в местных инициативах. Принимали участие 1-2 раза - 33,0\% мелитопольцев и 28,4\% людей с инвалидностью. Но при этом 27,5\% опрошенных людей с инвалидностью утверждают, что постоянно принимают участие в жизни города, что на 24,2\% больше, в сравнении с опытом обычных жителей г. Мелитополя (3,3\%). Этот показатель подтверждают и результаты качественных исследований (фокус-групп и глубинных интервью). Но при его интерпретации следует учитывать небольшую численность целевой группы (людей с инвалидностью), в сравнении с общим количеством жителей города. К тому же следует понимать, что любые инициативы 
в пространстве жизнедеятельности люди с инвалидностью воспринимают как своеобразный опыт участия.

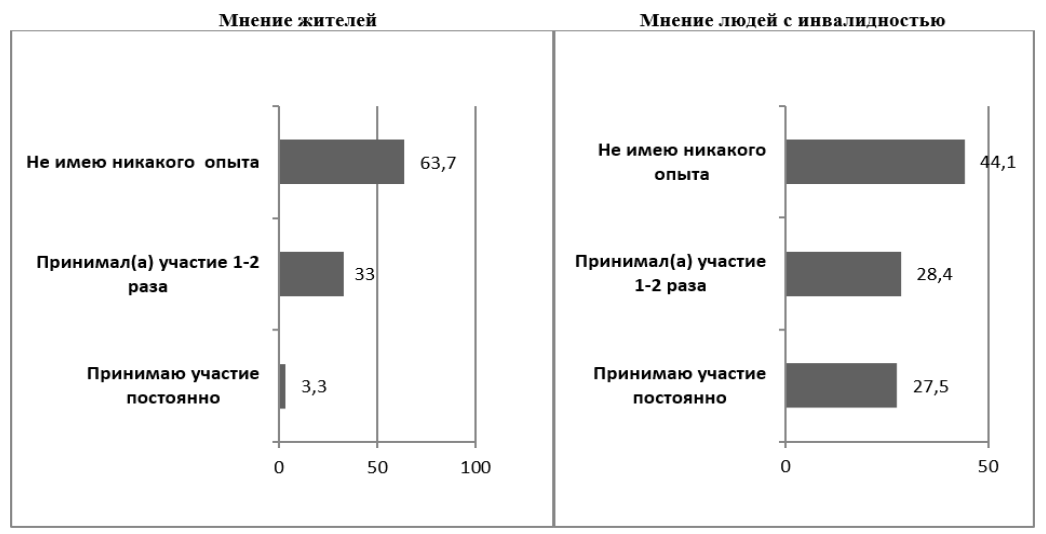

Рис. 4. Опыт гражданской активности (результаты анкетного опроса среди жителей города ( $n=100)$ и среди людей с инвалидностью $(\mathrm{n}=100)$

По мнению людей с инвалидностью, решение проблем города, в первую очередь, зависит от городской власти (91,1\%), при этом так же считают и жители города, но в данном случае на 55,9\% меньше (Рис. 5). 31,9\% горожан считают, что решать проблемы города можно, полагаясь на собственные силы. Всего 39,6\% людей с инвалидностью отмечают, что решение проблем города зависит от самих жителей города, 14,9\% от коммерческих организаций, 13,9\% - от общественных организаций. И только 1,0\% людей с инвалидностью считают, что все зависит от них самих, что на 12,2\% меньше, по сравнению с мнением жителей города $(13,2 \%)$.

17,6\% местных жителей считает основными преградами для участия в развитии города то, что имеют более важные собственные проблемы, к тому же это никому не нужно, что свидетельствует о безразличии к чужим проблемам. В то же время, только 2,0\% людей с инвалидностью среди препятствий называют безразличие к чужим проблемам, лень, апатию, не заинтересованность, 10,0\% - это никому не нужно и 6,0 - есть более важные собственные проблемы. 9,9\% жителей считают преградой уверенность, что ничего не получится, в то же время, люди с инвалидностью не отметили этот вариант вообще (0\%). 


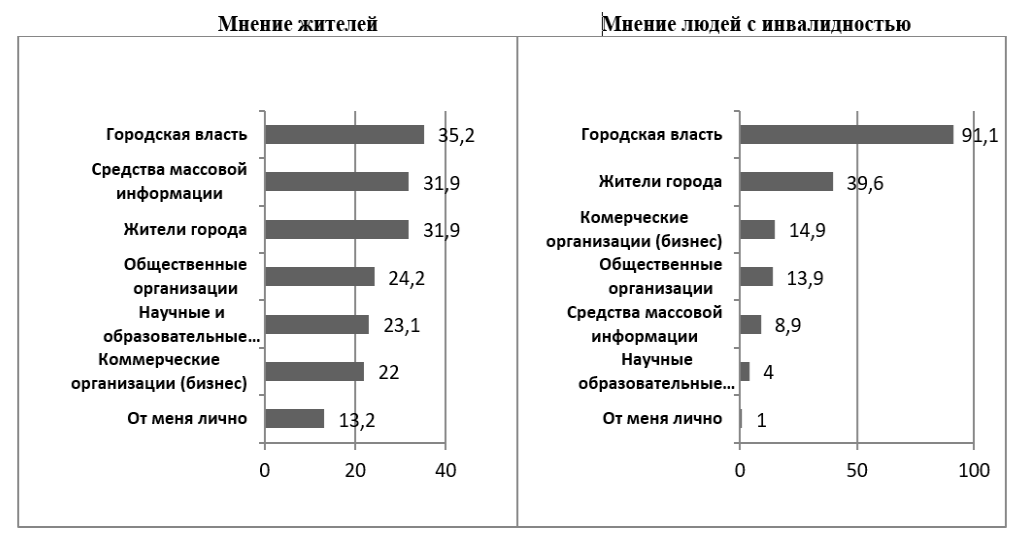

Рис. 5. Уровень зависимости решения проблем города от различных общественных институтов и граждан* (результаты анкетного опроса среди жителей города (n=100) и среди людей с инвалидностью $(\mathrm{n}=100)$

На рисунках 1-4 отображены лишь некоторые результаты комплексного исследования, которые подтвердили гипотезу о недостаточном уровне гражданской активности людей с инвалидностью и о необходимости системы работы для развития гражданской активности. Внешними причинами недостаточного уровня гражданской активности людей с инвалидностью являются: отсутствие городских образовательных Программ для людей с инвалидностью. Фактически действуют несколько ежегодных Программ поддержки людей с инвалидностью, но они направлены, в основном, на оказание медицинской и реабилитационной помощи; отсутствие образовательных Программ для людей с инвалидностью в содержании работы общественных организаций; низкая представленность людей с инвалидностью в общественных организациях города, что демонстрирует их недостаточную социальную активность и неосведомленность о деятельности таких организаций; представленность в общественных организациях людей с инвалидностью прежде всего большинством людей третьего (старшего) возраста; низкая представленность людей с инвалидностью среди студенческой молодежи от 0 до 4\% от общего количества; недостаточность в местных средствах массовой информации публикаций о жизни людей с инвалидностью, преодолении трудностей, их достижениях, как примеров проявления 
гражданской активности. Публикации являются отображением действительности, в которой люди с инвалидностью пока недостаточно граждански активны.

\section{Выводы}

Результаты комплексного социологического исследования показали, что включенность людей с инвалидностью в активную жизнь города является актуальной проблемой, решение которой находится, в первую очередь, в плоскости получения данной категорией населения определенных компетентностей в области общественной деятельности.

1. Для людей с инвалидностью является проблемой отсутствие культурных и образовательных мероприятий, состояние здоровья и др. Не менее важными их потребностями являются архитектурная доступность, материальное положение, доступность лекарств, возможности саморазвития и самореализации.

2. Люди с инвалидностью не обладают достаточным опытом гражданской активности. Причинами этого явления являются изоляция, неуверенность в своих силах, отсутствие знаний. Многие считают, что решение городских проблем сводиться в первую очередь к городской власти, а не к их гражданской активности и участию. Имеет место своеобразный потребительский подход, возможно, трансформированный в стереотип невозможности восприятия себя в роли «агента изменений». Качественной мотивацией для включения людей с инвалидностью в активную общественную деятельность могли бы стать совместные инициативы власти и общественных организаций, а также успешные примеры такой активности. Примером решения этой проблемы является организация и проведение совместных проектов социальной направленности для развития демократии.

3. В основном, люди с инвалидностью позиционируют себя как полноценные члены городской общины, обладающих желанием и возможностями что-то менять и делать, но не знающих, как именно можно что-то реализовывать. При этом треть горожан воспринимают людей с инвалидностью как активных жителей и считают причиной их пассивности, в первую очередь, неуверенность, определенные черты характера (обидчивость, закрытость), вызванные изоляцией, особенностями их здоровья. 
4. Большинство людей с инвалидностью имеют желание принимать участие в образовательных Программах и мотивируют это тем, что такая деятельность позволила бы им выйти из привычного, замкнутого круга общения (изоляции) и расширить круг своих социальных контактов, преодолеть страхи и переживания относительно своих способностей и возможностей, проявить гражданскую активность, получить дополнительные пути самореализации. Соответственно, процесс обучения и общения в его рамках позволил бы многим отвлечься от своих внутренних проблем (депрессии, отчаяния, стереотипов) и включиться в активную деятельность.

5. Направлениями обучения, по мнению людей с инвалидностью, должны быть Программы неформального образования, содержательными компонентами которых являются: знания основ правовой и законодательной базы, изучение делового украинского языка, навыки работы в команде, налаживания сотрудничества и взаимодействия, развития уверенности в себе, саморазвития и коммуникации.

6. При разработке образовательных Программ для людей с инвалидностью важно учитывать, что наиболее приемлемыми формами обучения (организационный компонент) для них являются тренинги и мастер-классы, с включенными дискуссиями, сочетанием индивидуальной и групповой (командной) работой. Так же следует максимально учитывать индивидуальные особенности данной категории населения, что предполагает фасилитацию, гармоничное сочетание в занятиях рабочих и досуговых моментов (эмоциональный компонент), а также частоту и длительность занятий - не более 2-4 часов в неделю.

Команда Благотворительной организации «Социальный фонд» разработала образовательную Программу «Инклюзивная мастерская 3D демократии - думаем, действуем, достигаем», направленную на удовлетворение образовательных потребностей людей с инвалидностью. Она стартует в феврале 2019 и будет включать 3 модуля (40 часов): интерактивные лекции «Деловой украинский язык и культура общения»; мотивационные тренинги «Мы и другие. Другие и мы»; деловая игра «Мы и государство». Цель Программы - способствовать развитию гражданских компетенций людей с инвалидностью для расширения их возможностей эффективного участия в общественной жизни и повышения уровня их гражданской активности. Спецификой 
Программы является то, что она: интегрирует основы философских, аксиологических, политических, правовых и социально-психологических знаний; формирует мировоззрение, личностные качества и ценностные ориентиры демократического общества; ориентирует на включение людей с инвалидностью в общественную жизнь и повышение гражданской активности; предполагает необходимость фасилитации: (учет индивидуальных и психологических особенностей, состояние здоровья, степень утомляемости, трудности передвижения, психологические комплексы, связанные с изоляцией, отсутствием навыков общения, вторичными последствиями заболевания и др.); предусматривает трехуровневое обучение: усвоение знаний; развитие умений, навыков, отношений; получение социального опыта эффективного участия в общественной жизни и повышения гражданской активности.

\section{Literatura [Литература]}

Alyeksyeyenko T. (red.), (2009), Sotsial'na pedahohika: slovnyk-dovidnyk, Planer, Vinnytsya. [Алєксєєнко Т. (ред.), (2009), Соціальна педагогіка: словник-довідник, Планер, Вінниця].

Babkina M., (2017), Kompetentnisnyy pidkhid do formuvannya aktyvnoyi hromadyans'koyi pozytsiyi molodoyi osobystosti, [v:] Suchasni tendentsiyi ta faktory rozvytku pedahohichnykh ta psykholohichnykh nauk, Kyyiv. [Бабкіна М., (2017), Компетентнісний підхід до формування активної громадянської позиції молодої особистості, [в:] Сучасні тенденції та фактори розвитку педагогічних та психологічних наук, Київ].

Bezverkha T., (2008), Derzhavne upravlinnya etnonatsional'nymy vidnosynamy $v$ konteksti formuvannya ukrayins'koyi natsional'noyi ideyi, DRIDU, Dnipropetrovs'k. [Безверха T., (2008), Державне управління етнонаціональними відносинами в контексті формування української національної ідеї, ДРІДУ, Дніпропетровськ].

Hollob R., Krapf P., Vaydinher V. (red.), (2016), Navchayemo demokratiyi: Bazovi materialy z osvity dlya demokratychnoho hromadyanstva ta osvity z prav lyudyny dlya vchyteliv, Osnova, Kyyiv. [Голлоб Р., Крапф П., Вайдінгер В. (ред.), (2016), Навчаємо демократії: Базові матеріали з освіти для демократичного громадянства та освіти з прав людини для вчителів, Основа, Київ]. 
Khartiya Rady Yevropy z Osvity dlya demokratychnoho hromadyanstva ta osvity z prav lyudyny, (2010), www.coe.int/edc [11.03.2019], [Хартія Ради Європи з Освіти для демократичного громадянства та освіти з прав людини, (2010), www.coe.int/edc [11.03.2019]].

Luk"yanova L. (red.), (2011), Kontseptsiya osvity doroslykh v Ukrayini, Nizhyn. [Лук'янова Л. (ред.), (2011), Концепція освіти дорослих в Україні, Ніжин].

Salamankskaya deklaratsyya, (2000), Ramky deystvyy po obrazovanyyu lyts s osobыmy potrebnostyamy, Kyev. [Саламанкская декларация, (2000), Рамки действий по образованию лиц с особыми потребностями, Киев].

Shevtsiv Z., (2016), Osnovy inklyuzyvnoyi pedahohiky: pidruchnyk, Tsentr uchbovoyi literatury, Kyyiv, [Шевців 3., (2016), Основи інклюзивної педагогіки: підручник, Центр учбової літератури, Київ].

Stepanenko V., (2001), Problemy formuvannya hromadyans'koho suspil'stva v Ukrayini: instytuty, praktyky, tsinnosti, http://isoc.com.ua/institute/ St2.doc., [11.03.2019], [Степаненко В., (2001), Проблеми формування громадянського суспільства в Україні: інститути, практики, цінності, http://isoc.com.ua/institute/St2.doc., [11.03.2019]].

Zahal'noderzhavna prohrama "Natsional'nyy plan diy z realizatsiyi Konventsiyi pro prava invalidiv ta rozvytku systemy reabilitatsiyi invalidiv» na period do 2020 roku. [Загальнодержавна програма «Національний план дій з реалізації Конвенції про права інвалідів та розвитку системи реабілітації інвалідів» на період до 2020 року]. 